\title{
Relationship between Tertiary Institutions' Policy Statements (Appointments and Promotion) Implementations and Academic Staff Job Satisfaction in Adamawa State, Nigeria
}

\author{
Kwaji Tizhe Takwate \\ Adamawa State University, Mubi, Nigeria \\ Department of Science Education \\ Email: Taquate [AT] yahoo.com
}

\begin{abstract}
This study determined the relationship between tertiary institutions' policy statements (appointment and promotion) implementations and academic staff job satisfaction in Adamawa State, Nigeria. Descriptive survey research design was adopted for the study. The total population for the study was 787 comprising 119 school administrators and 668 academic staff. The entire school administrators (119) and 250 academic staff was proportionately sampled for the study. Personnel Appointment and Promotion Policy Statement Questionnaire (PAPPSQ) and Academic Staff Job Satisfaction Questionnaire (ASJSQ) were used for data collection. The reliability coefficient of the research instruments are 0.94 and 0.92 respectively. Means, Standard Deviation and z-test was used to answer research question and test the null hypotheses respectively. Strict adherence to the implementation of institutional appointment and promotion policy statements by school management was rated low and high respectively by the respondents. The study revealed that school administrators and academic staff are dissatisfied with the implementation of these policies. A significant difference was found between the perceptions of the respondents on the implementation of these policies by the tertiary institutions. Based on these findings, it was recommended among others that minimum qualification of first degree or its equivalent for appointment as an academic staff should be maintained and indicated in every vacancy advertisements by all state owned tertiary institutions in Adamawa state, staff should be promoted based on either research publications, time-inrank or academic qualification as when due and monitoring teams should be set up by the institutions governing bodies to ensure strict adherence to implementation of all policy statements.
\end{abstract}

Keywords--- Implementation, Institutional-Appointment, Institutional-Promotion, Policy-statement, Tertiary Institutions

\section{INTRODUCTION}

The level of educational development attainable by a nation (United Nation Educational, Scientific and Cultural Organisation, UNESCO, 1999) depends on the human resources utilized for the realization of goals which invariably depends on the personnel policies implemented by the educational institutions. Personnel policy according to Ubeku (2005) is a written statement of an organisation's goals and intentions concerning matters that affect people in an organisation which covers all aspect of appointment and promotion of its employees. Okonkwo (2007) viewed that, such policies are adequately implemented in order to motivate staff to be committed to work. This is because poor implementation of these policies in any organisation leads to ineffectiveness of workers or even collapse of the organisation (Batchelder \& Alexander, 2009).

Granger and Max (1992) attributed the problem of appointment policies in educational institutions to disparities in wages and non adherence to criteria for appointment as factor affecting job satisfaction. Regardless of the criteria used, Chimanikire, Mutandwa, Gadzirayi, Muzondondo and Mutandwa (2007) revealed that the type of appointment given to academic staff affects their job satisfaction, because employees with permanent or full-time appointments are more satisfied with their job than those with temporary appointment. That is why as much as possible, the selections and appointment of persons to all academic positions should be treated without regard to ethnicity, State of origin, religion, gender, age, political affiliation, or disability (Takwate, 2011).

Academic staff job satisfaction (Okonkwo, 1997) is largely dependent upon the extent to which the job and everything associated with it meets their needs and wants; and for teaching to be recognised and respected as a profession, adequate provisions for promotion must be assured. In addition Edem (1998) revealed that teachers in the tertiary institutions in Nigeria are demoralized because of the disparities in opportunity for promotion and this mostly leads to mass exodus of 
teachers to more lucrative employment. Staff promotion is the change of assignment from a job of a lower level to one of a higher level within the organisation whereby the new level normally provides an employee with an increase in pay and status (Chruden \& Sherman, 1976). The opportunity to gain promotion by employees can serve as an incentive for improving capacities, performance, and improvement of employee's efficiency and morale (Human Resource Guide, 2000).

From the foregoing, it could be observed that adequate implementation of institutional policy statements leads to high job satisfaction. Some of these policies could be more frequently implemented than the others with the academic staff, students and the society bearing the consequences. More importantly, the implementation of these policies could influence the job satisfaction of academic staff in tertiary institutions. State owned tertiary institutions in Adamawa state seem to be plagued by the aforementioned which probably result in exodus of the academic staff from these institutions and frequent strike actions by the various trade unions.

Reasons for these grievance or dissatisfaction according to the unions or from personal contact with any academic staff from these institutions revealed that appointments and promotions of academic staff are done based on ethnicity, State or Local Government Area of origin, religion, political affiliation among others and not according to rules or policies guiding the appointments and promotion of staff or as stipulating in the institutions' governing laws. These claims cannot be admitted without an in-depth investigation of how academic staff are actually appointed and promoted by these institutions. Hence the crux of this study to examine the perceptions of school administrators and academic staff on the implementations of institutional appointment and promotion policies statements and academic staff job satisfaction among state owned tertiary institutions of Adamawa State, Nigeria.

\section{STATEMENT OF THE PROBLEM}

Job satisfaction of workers in an organisation depends on the perception of the employees about how policies are being implemented and how satisfied they are with the implementation (Eton, 1984). The finding by Kazeem (1999) revealed that academic staff in tertiary institutions and other school workers tend to remain contented and reasonably motivated as long the employees are employed based on laid down criteria, salaries are paid on time, and they are promoted regularly. The implication for none or inadequate implementation of appointment and promotion policies (Amadi in Adelabu, 2005) often leads to strikes and mass exodus to other lucrative organizations while some retire voluntarily and go into private businesses.

However, despite the benefits that could be derived from the strict implementation of these policies by institutions, it is haphazardly carried out by the tertiary institutions in Nigeria. The case state owned tertiary institutions in Adamawa state is not different from what is obtainable in other states in Nigeria because the struggle by the academic staff to press home their demands in terms of strict adherence to criteria for staff appointment and better working conditions, by tertiary institutions in Adamawa State have been one of the causes of crisis between school administration and trade unions among others (Bello, 2004). In the same vein several research studies have identified a variety of other reasons why academic staff of tertiary institutions leaves their profession entirely. These include personal reasons such as lack of salary and benefits (Ingersoll \& Smith, 2003), poor working conditions (Hanushek, Kain \& Rivkin, 2004), better job opportunities outside education for higher ability teachers (Bello, 2004), job dissatisfaction (Rhodes, 2004), lack of promotion (Barnett \& McCormick, 2004), increased student enrolment (Imazeki, 2005) and poor implementation of personnel policies (Takwate, 2011). With these attentions to other factors of motivation, one cannot be totally convinced with it as the only factors that affect academic staff job satisfaction in Adamawa State tertiary institutions without exploring other areas. It is therefore against this background that this study is set out to assess the perceptions of school administrators and academic staff on the implementation of institutional policy statements and job satisfaction of academic staff in Adamawa State, Nigeria.

\section{RESEARCH QUESTIONS}

1. What are the perceptions of school administrators and academic staff on the implementation of appointment policy statements among State owned tertiary institutions in Adamawa State?

2. What are the perceptions of school administrators and academic staff on the implementation of promotion policy statements among State owned tertiary institutions in Adamawa State?

3. What is job satisfaction of academic staff with the implementation of appointment and promotion policy statements by State owned tertiary institutions in Adamawa State? 


\section{RESEARCH HYPOTHESES}

Ho1: There is no significant difference between the mean responses of school administrators and academic staff on how they perceive the implementation of appointment policy statements by State owned tertiary institutions in Adamawa State, Nigeria.

Ho2: There is no significant difference between the mean responses of school administrators and academic staff on how they perceive the implementation of promotion policy statements by State owned tertiary institutions in Adamawa State, Nigeria.

\section{METHODOLOGY}

Descriptive survey research design was adopted for the study. This study was delimited to determine the implementation of institutional appointment and promotion policy statements and academic job satisfaction of State owned tertiary institutions in Adamawa State, Nigeria. Adamawa State University Mubi, Adamawa State College for Health and Technology Mubi, College of Education Hong, College for Legal Studies Yola, Adamawa State College for Nursing and Midwifery Yola, College of Agriculture Ganye and Adamawa State Polytechnic Yola were used for the study. The total population for the study was 787 comprising 119 school administrators and 668 academic staff. The entire school administrator (119) was used and 250 academic staff was proportionately sampled from the seven tertiary institutions in Adamawa State. Personnel Appointment and Promotion Policy Statement Questionnaire (PAPPSQ) and the Minnesota Satisfaction Questionnaire (MSQ) (Weiss et al, 1967) was adopted and titled Academic Staff Job Satisfaction Questionnaire (ASJSQ) were used for data collection. The questionnaires were structured on a five-point response scale - Strongly Agree (5), Agree (4), Undecided (3), Disagree (2) and Strongly Disagree (1) and Very Satisfied (5), Satisfied (4), Neutral (3), Dissatisfied (2) and Very Dissatisfied (1) respectively. The reliability coefficient of the research instruments are 0.94 and 0.92 respectively. Means, standard deviation and z-test were used to answer the research questions and test the null hypotheses. The decision to accept or reject an item in the questionnaire was based on the upper limit of point 3 which is 3.50. Any item that yielded mean above 3.50 was regarded as agreed or satisfied any mean below 3.50 was regarded as disagreed or dissatisfied and any mean at 3.50 was regarded as undecided or neutral. The decision to reject or not to reject null hypothesis $\left(\mathrm{Ho}_{1}-\mathrm{Ho}_{2}\right)$ was based on the calculated value of the test statistic at 0.05 level of significance. A null hypothesis is rejected if the calculated value of $\mathrm{z}$-test is greater than the critical value or level of significance. 
Research Question 1: What are the perceptions of school administrators and academic staff on the implementation of appointment policy statements among State owned tertiary institutions in Adamawa State? Results as shown in Table 1:

Table 1: Mean and Standard Deviation of School Administrators and Academic Staff Perception of Appointment Policy Statements Implementation by State Owned Tertiary Institutions in Adamawa State

\begin{tabular}{|c|c|c|c|c|c|c|c|}
\hline \multirow[b]{2}{*}{$\mathrm{S} / \mathrm{N}$} & \multirow[t]{2}{*}{ ITEMS } & \multicolumn{3}{|c|}{ School Administrators } & \multicolumn{2}{|c|}{ Academic Staff } & \multirow[b]{2}{*}{ Remark } \\
\hline & & $\bar{X}$ & $\Delta$ & Remark & $\bar{X}$ & $\delta$ & \\
\hline 1 & $\begin{array}{l}\text { I have knowledge of academic staff } \\
\text { appointment criteria of this school }\end{array}$ & 4.19 & 0.38 & Agree & 3.40 & 0.22 & Disagree \\
\hline 2 & $\begin{array}{l}\text { Cognate experience of applicant is considered } \\
\text { for appointment }\end{array}$ & 3.89 & 0.34 & Agree & 3.44 & 0.22 & Disagree \\
\hline 3 & $\begin{array}{l}\text { The school adhere strictly to minimum } \\
\text { qualification or its equivalent for appointment } \\
\text { of academic staff }\end{array}$ & 4.72 & 0.45 & Agree & 2.26 & 0.24 & Disagree \\
\hline 4 & $\begin{array}{l}\text { The qualifications needed for academic } \\
\text { position are included in all advertisement of } \\
\text { vacancies }\end{array}$ & 4.47 & 0.42 & Agree & 3.06 & 0.21 & Disagree \\
\hline 5 & $\begin{array}{l}\text { Retirement age of } 60 \text { years or } 35 \text { years of } \\
\text { service for academic staff on permanent } \\
\text { appointment is satisfactory }\end{array}$ & 4.87 & 0.41 & Agree & 3.78 & 0.24 & Agree \\
\hline 6 & $\begin{array}{l}\text { Probationary period of two years for academic } \\
\text { staff is satisfactory }\end{array}$ & 4.54 & 0.42 & Agree & 3.23 & 0.21 & Disagree \\
\hline 7 & $\begin{array}{l}\text { Appointments of academic staff are made } \\
\text { subject to satisfactory medical evidence of } \\
\text { good health }\end{array}$ & 4.30 & 0.40 & Agree & 2.47 & 0.22 & Disagree \\
\hline \multirow[t]{2}{*}{8} & $\begin{array}{l}\text { In-service are given to academic staff to go for } \\
\text { training }\end{array}$ & 4.44 & 0.41 & Agree & 3.28 & 0.21 & Disagree \\
\hline & Grand Mean & 4.43 & 0.40 & Agree & 3.12 & 0.22 & Disagree \\
\hline
\end{tabular}

Table 1 shows the mean and standard deviation of items on implementation of appointment policy statements by State owned tertiary institutions in Adamawa State. The grand mean $4.43 \pm 0.40$ for all of the items by school administrators indicates adequate implementation of the policy statement while the academic staff perceptions indicated non implementation except for item five (3.12 \pm 0.22$)$ with grand mean 3.12. 
Research Question 2: What are the perceptions of school administrators and academic staff on the implementation of promotion policy statements among State owned tertiary institutions in Adamawa State? Results as shown in Table 2:

Table 2: Means and Standard Deviation of School Administrators and Academic Staff Perception of Promotion Policy Statements Implementation by State Owned Tertiary Institutions in Adamawa State

\begin{tabular}{|c|c|c|c|c|c|c|c|}
\hline \multirow[t]{2}{*}{$\mathrm{S} / \mathrm{N}$} & \multirow[t]{2}{*}{ ITEMS } & \multicolumn{3}{|c|}{ School Administrators } & \multicolumn{2}{|c|}{ Academic Staff } & \multirow[b]{2}{*}{ Remark } \\
\hline & & $\bar{X}$ & $\delta$ & Remark & $\bar{X}$ & $\Delta$ & \\
\hline 9 & $\begin{array}{l}\text { I have knowledge of the criteria used by this } \\
\text { school for promoting academic staff }\end{array}$ & 4.19 & 0.38 & Agree & 3.40 & 0.22 & Disagree \\
\hline 10 & $\begin{array}{l}\text { Unless it's in the interest of the institution, a } \\
\text { staff must satisfy the minimum qualification } \\
\text { before he/she is promoted }\end{array}$ & 3.49 & 0.31 & Disagree & 3.37 & 0.22 & Disagree \\
\hline 11 & $\begin{array}{l}\text { Promotion of academic staff is influenced by } \\
\text { either research time-in-rank }\end{array}$ & 4.49 & 0.42 & Agree & 3.98 & 0.25 & Agree \\
\hline 12 & $\begin{array}{l}\text { Academic staff are considered for promotion } \\
\text { only on the recommendation of the Head of } \\
\text { Department }\end{array}$ & 4.59 & 0.44 & Agree & 1.00 & 0.36 & Disagree \\
\hline 13 & $\begin{array}{l}\text { Academic staff promotion is based on } 3 \text { years } \\
\text { time in rank }\end{array}$ & 4.13 & 0.37 & Agree & 3.87 & 0.25 & Agree \\
\hline 14 & $\begin{array}{l}\text { The guidelines for promotion are made by the } \\
\text { Promotion Committee and approved by the } \\
\text { governing council }\end{array}$ & 4.45 & 0.41 & Agree & 2.38 & 0.23 & Disagree \\
\hline 15 & $\begin{array}{l}\text { The school can refuse to promote a staff even if } \\
\text { he/she is due for it }\end{array}$ & 4.40 & 0.41 & Agree & 1.66 & 0.29 & Disagree \\
\hline \multirow[t]{2}{*}{17} & $\begin{array}{l}\text { Academic staff are promoted as when due } \\
\text { without delay }\end{array}$ & 3.85 & 0.33 & Agree & 3.33 & 0.21 & Disagree \\
\hline & Grand Mean & 4.20 & 0.38 & Agree & 4.48 & 0.03 & Agree \\
\hline
\end{tabular}

Result of analysis in Table 2 shows the mean and standard deviation of items on implementation of promotion policy statements among State owned tertiary institutions in Adamawa State. The grand mean of the school administrators and academic staff 4.20 and 4.48 respectively indicates that promotion policy statement is implemented accordingly. 
Research Question 3: What is job satisfaction of academic staff with the implementation of appointment and promotion policy statements by State owned tertiary institutions in Adamawa State? Results as shown in Table 3:

Table 3: Means and Standard Deviation of School Administrators and Academic Staff Perceptions on Job Satisfaction of Academic Staff with the Implementation of Institutional Appointment and Promotion of Policy Statements by State Owned Tertiary Institutions in Adamawa State

\begin{tabular}{|c|c|c|c|c|c|c|c|}
\hline \multirow[t]{2}{*}{$\mathrm{S} / \mathrm{N}$} & \multirow{2}{*}{$\begin{array}{l}\text { Question items } \\
\text { How satisfied are with the following: }\end{array}$} & \multicolumn{3}{|c|}{ School Administrators } & \multicolumn{2}{|c|}{ Academic Staff } & \multirow[b]{2}{*}{ Remark } \\
\hline & & $\bar{X}$ & $\delta$ & Remark & $\bar{X}$ & $\Delta$ & \\
\hline 18 & $\begin{array}{l}\text { Minimum qualification of first degree or its } \\
\text { equivalent for appointment }\end{array}$ & 4.09 & 0.36 & VS & 4.85 & 0.34 & VS \\
\hline 19 & $\begin{array}{l}\text { Probationary period of } 2 \text { years before } \\
\text { confirmation of appointment }\end{array}$ & 3.87 & 0.35 & VS & 4.48 & 0.30 & VS \\
\hline 20 & $\begin{array}{l}\text { Retirement of age of } 65 \text { years or } 35 \text { years of } \\
\text { service }\end{array}$ & 4.78 & 0.47 & VS & 4.78 & 0.34 & VS \\
\hline 21 & Job security & 3.87 & 0.34 & VS & 1.96 & 0.26 & VD \\
\hline 22 & Opportunities for promotion & 3.20 & 0.29 & VD & 4.42 & 0.30 & VS \\
\hline 23 & Personal experience with promotion process & 3.32 & 0.30 & VD & 2.33 & 0.20 & VD \\
\hline 24 & $\begin{array}{l}\text { Recognition of research activity for } \\
\text { promotion purposes }\end{array}$ & 3.18 & 0.29 & VD & 1.84 & 0.27 & VD \\
\hline 25 & $\begin{array}{l}\text { Your overall job satisfaction with the } \\
\text { implementation of appointment policy in } \\
\text { your school }\end{array}$ & 3.65 & 0.32 & VS & 2.17 & 0.24 & VD \\
\hline \multirow[t]{2}{*}{26} & $\begin{array}{l}\text { Your overall satisfaction with the } \\
\text { implementation of promotion policy in your } \\
\text { school }\end{array}$ & 3.74 & 0.33 & VS & 2.08 & 0.25 & VD \\
\hline & Grand Mean & 3.74 & 0.33 & VS & 3.21 & 0.28 & VD \\
\hline
\end{tabular}

Result of analysis in Table 3 shows the job satisfaction of academic staff with the implementation of appointment and promotion policy statements by State owned tertiary institutions as perceived by school administrators and academic staff in Adamawa State. The grand mean 3.74 indicates that academic staff are very satisfied as perceived by school administrators and the grand mean 3.21 of academic staff perception indicates that academic staff are very dissatisfied with how these policies (appointment and promotion) are implemented.

Ho1: There is no significant difference between the mean responses of school administrators and academic staff on how they perceive the implementation of appointment policy statements by State owned tertiary institutions in Adamawa State, Nigeria. Results in Table 4:

Table 4: z-test of differences between School Administrators and Academic Staff Perception of Appointment Policy Statements Implementation

\begin{tabular}{lccccccc}
\hline Respondents & $\mathrm{n}$ & $\mathrm{df}$ & $\bar{x}$ & S.D & z-cal. & z-crit. & Remark \\
\hline School Administrators & 119 & 347 & 4.37 & 0.338 & 24.523 & 1.96 & Significant \\
Academic Staff & 230 & & 3.03 & 0.544 & & & \\
\hline
\end{tabular}

Table 4 reveals a significant difference between the mean perception of school administrators and academic staff on the implementation of appointment policy statements by State owned tertiary institutions in Adamawa State. Table 4 shows that the z-value calculated (24.52) is greater than the critical (1.96) at 0.05 level of significance. 
Ho2: There is no significant difference between the mean responses of school administrators and academic staff on how they perceive the implementation of promotion policy statements by State owned tertiary institutions in Adamawa State, Nigeria. Results in Table 5:

Table 5: z-test of differences between School Administrators and Academic Staff Perception of Promotion Policy Statements Implementation

\begin{tabular}{lccccccc}
\hline Respondents & $\mathrm{n}$ & $\mathrm{df}$ & $\bar{x}$ & S.D & z-cal. & z-crit. & Remark \\
\hline School Administrators & 119 & 347 & 4.21 & 0.36 & 11.95 & 1.96 & Significant \\
Academic Staff & 230 & & 3.00 & 1.07 & & & \\
\hline
\end{tabular}

Table 5 shows that the $\mathrm{z}$-value calculated (11.948) at 0.05 level of significance is greater than the critical value (1.96). Thus, the null hypothesis is rejected and the alternative accepted. This signified that there is a significant difference between how school administrators and academic staff perceive the implementation of promotion policy statements among the State owned tertiary institutions in Adamawa State.

\section{DISCUSSION OF FINDINGS}

This study revealed that school administrators and academic staff agreed that the implementation of appointment policy statements by tertiary institutions of Adamawa State is haphazardly carried out by the school management. This is evident by the grand mean score $3.03 \pm 1.94$. The respondents perceive that the policy is not implemented as contained in the conditions for recruiting academic staff in Adamawa State by tertiary institutions. The low rating is evident also by the fact that probably not all of respondents are aware of the criteria used by these institutions for appointing academic staff as revealed by their mean score $3.40 \pm 0.22$. That means, either the academic staff were not given the conditions of service manual or they did not read it (Dehlor, 2006). The implication is that, it is good as revealed by McMamara (2010) for all institutions to ensure that all academic staff have the conditions of service manual and set aside a half day per year for employees to review the policies to ensure that they are up to date.

On the implementation of promotion policy statements, the respondents have agreed that they are not conversant with the criteria used in promoting academic staff by tertiary institutions but notwithstanding the study revealed that the institutional promotion policy statements were implemented as shown in Table 2 with grand mean score of 3.61 \pm 7.21 . This finding is supported by Ogunbameru (1989) who found that when respondents are not aware of the criteria used in executing some task in an organization they may give wrong impression about it. Supporting the importance of implementation promotion policy statements according to guide line by tertiary institutions Edem (1998); Truell, Price and Joyner (1998); Hickson and Oshagbemi (1999); Brewer and McMahan-Lander (2003) revealed that promotion opportunity is a determinant of job satisfaction. Mosley, Meggins and Pietri (1993) equally maintain that job satisfaction of staff is strongly influenced by the rewards that the individual receives such implementation.

Result in Table 3 indicates that academic staff in Adamawa state are dissatisfied with the implementation of the institutional appointment and promotion policy statements. This is due to lack of job security and inadequate recognition of research activities or publications for promotion purposes among others. Supporting this finding Sen (1990) and Rosee (1991) revealed that the opportunity to be secured on the job and gain promotion can serve as an incentive for individuals to improve further their capacities and their performance. These can equally serve as a reward and subsequently improve employee efficiency and morale

\section{RECOMMENDATIONS}

Based on the findings of this study, the following recommendations were made to improve the implementation of institutional appointment and promotion policy statements by state owned tertiary institutions in Adamawa state.

1. Minimum qualification of degree or its equivalent for appointing academic staff should be maintained and indicated in vacancy advertisements by all tertiary institutions in the state. The qualifications and experience needed for any academic position should be included in all advertisement of vacancies by the schools. 
2. Academic staff should be promoted by the institutions based on either research publications, time-in-rank or academic qualification as when due.

3. Academic staff should not be considered for promotion until at least one year has elapsed since the date of his/her last promotion.

4. Each academic staff should be given the conditions of service manual for review and be up-to-date.

5. The institutions governing bodies (NUC, NBTE and NCCE) should form monitoring team that will ensure institutions adhere strictly to their institutional appointment and promotion policy statements.

\section{REFERENCES}

- Ajayi, K. (1988). Approaches to understanding human behaviour in complex organisations: A Personnel management point of view. Journal of Educational Leadership, 3(1): 190.

- Amadi, P. (1983). The dilemma of the Nigerian teacher. In M.A. Adelabu. Teacher motivation and incentives in Nigeria. Ekiti State SPEB Initiative. Ibadan: Gabesther Educational Publishing Company.

- Batchelder, J. S. \& Alexander, R. C. (2009). Effects of personnel policy on public school administration paradigm shift in Adamawa State: From merit to neo-managerial. Journal of Social Science, 21(2): 153 - 159.

- Barnett, K. \& McCormick, J. (2004). Leadership and individual school administrator-teacher relationship in schools. Educational Administration Quarterly, 40 (3): 406 - 434.

- Bello, S. T. (2004). Job satisfaction among school teachers in Adamawa State school system: Some implication for school administrators. Business and Educational Research Journal, 4(1).

- Brewer, E.W. \& McMahan-Lander, J. (2003). Job satisfaction among industrial and technical teachers educators. Journal Industrial Teacher Educator, 40: 28 - 36.

- Chimanikire, P. et al (2007). Factors affecting job satisfaction among academic professionals in tertiary institutions in Zimbabwe. African Journal of Business Management, 1(6): 166-175.

- Chruden, H. J. \& Sherman, A. W. (1976). Personnel management. ( $5^{\text {th }}$ ed.). Ohio. South- Western Publishing Co. P. 102-118, 345-347.

- Dehlor, S. A. (2006). Towards academic staff satisfaction of working conditions of service at HO Polytechn Ghana. (Unpublished M.Sc Dissertation, University of Twente Netherland). Retrieved April 28, 2018 from http//www.scriptie_Dehlor.pdf.

- Edem, D.A. (1998). Introduction to educational administration in Nigeria. Ibadan: Spectrum Books Limited.

- Eton, E.O. (1984) Causes of indiscipline in teachers. Journal of Cross River Educator. 3(1): 39 - 45.

- Granger, R. C. \& Max, E. (1992). The policy implications of job satisfaction ratings for recruiting and retaining early childhood teachers. Child and Youth Care Forum, 21(4).

- Hanushek, E. A., Kain, J. F., \& Rivkin, S. G. (2004). Why public schools lose teachers: A case of Adamawa State tertiary institutions. Journal of Human Resources, 39(2): 326 - 354.

- Herzberg, F. (1959). The Motivation to work. New York: John Wiley \& Sons. P.115

- Hickson, C. \& Oshagbemi, T. (1999). The effect of age on the satisfaction of academics with teaching and research. International Journal Social Economic, 26: 537 - 544. 
- Human Resources Guide (2000). Compensation: Outline and definitions. Retrieved October 12, 2017 from www.hrguide.com.

- Imazeki, J. (2005). Teacher salaries and teacher attrition. Economics of Education Review 24(7):431 - 449.

- Ingersoll, R. M, \& Smith T. M. (2003). The wrong solution to the teacher shortage. Educational Leadership, 60(8), 30-33. Retrieved July 25, 2018 from http://www.ed.gov/inits/Math/glenn/compapers.html.

- Kazeem, S. O. (1999). Correlates of job motivation of workers in selected public and private tertiary institutions in Osun State, Nigeria. . In K. W. Bukar. Studies in education: Theory and practice. Jimeta-Yola: Alvari Communication Ltd.

- McMamara, C. (2010). Personnel Policies and Records Management. Retrieved May 25, 2018 From http://www.managementthelp.org/policies/policies.htm.

- Mosley, D. C., Meggins, L. C. \& Pietri, P. H. (1993). Supervisory management. The art of empowering people. Cincinnati, OH: South-Western Publishing Company.

- Ogunbameru, V.O. (1989). A study of personnel policies of teaching staff in higher institutions of learning in Anambra State. Research in Education, 71(3): 67-81. Retrieved August 31, 2018, from http//.www.EBSCOhost.

- Okonkwo, S.N. (2007). Job Satisfaction and the Work Behaviour of Nigerian Teachers. In A. Ndu., L. O. Ocho \& B. S. Okeke: Dynamics of educational administration and management: The Nigerian perspective. Anambra: Meks Publishers Ltd.

- $\quad$ Rhodes, C. (2004). Strategic valuing and supporting teachers. Research in Education, 71(3): 67 - 81. Retrieved August 31, 2018, from EBSCOhost database.

- Rosee, R. W. (1991). Comparison of employee turnover in food and beverage and other departments in hotel properties. Ann Arbor, MI: UMI Dissertation Services. In A. H. Feinstein, W. F. Harrah \& D. Vondrasek: A study of relationships between job satisfaction and organisational commitment among restaurant employees.

Retrieved July 29, 2018 from http://www.aasa.org/Advocacy/2-1-99rural.htm

- Sen, B. (1990). Technology, Manpower Planning and Education. The Education Quarter Journal, 22(1): 3.

- Takwate, K. T. (2011). Implementation of institutional personnel policy and academic staff job satisfaction among state owned tertiary institutions of Adamawa state. M.Ed. Thesis, Modibbo Adama University of Technology, Yola, Adamawa State.

- Truell, A. D., Price, W. T., \& Joyner, R. I. (1998). Job satisfaction among community college occupational technical faculty community. College Journal Residence Practice, 22: 111-122.

- Ubeku, A.K. (2005). Personnel management in Nigeria. Benin-City: Ethiope Publishing Corporation. P. 17

- United Nations Educational, Scientific and Cultural Organization (1999). Implementations of personnel policy. Item of the provisional agenda during the 157 Executive Session. Paris, 31 August. Retrieved on April 27, 2018 from http//www.excutive_10session.Paris.pdf. 